\title{
Unpublished Post-War Writing and Emergent Gay Cultures
}

\author{
CHRIS BRICKELL
}

The 1950s and '60s were pivotal decades in the emergence of modern gay life. New Zealand's cities expanded rapidly after the end of the war, and the size of homosexual networks grew quickly. There were profound contradictions too. While many men partied, others were imprisoned for same-sex activity. A homemade queer literature accompanied these changes, and four examples illustrate the tensions of the time. The first, an essay called "De Profundis for Today," was the work of Dunedin businessman Ernie Webber, who wrote it in Mt Eden Prison in 1957. The second piece, an early 1960s novel titled "The Rock Orchid," is by Bert Pimley, a fellow inmate of Webber at Mt Eden. The third and fourth pieces, short essays by Auckland man Don Goodsell, are very different in their context and tone. The evocatively titled "Did You Ever See a Dream Limping?" and "The Night is Young and We're So Beautiful" tell not of imprisonment but of the social opportunities of New Zealand's cities during the 1960s.

Few people know about these pieces of writing, at least not in the field of New Zealand literature or gay literature. They were never published. For many years, Webber's and Pimley's stories sat unconsulted in the Hocken Library in Dunedin. These were catalogued only recently. Goodsell's stories, though, circulated among men in New Zealand's gay communities during the 1960s and since. None of these is a masterpiece of literature- "De Profundis" is sketchy and exists in several drafts with jottings in the margins - but each is interesting in its own way. These tell us about the place of writing in gay life and the texture and complexities of experience that emerge in vastly different settings. What was it like to be imprisoned? What kinds of ideas and practices of sexuality took shape in jail? What fun could be had in the private gay party circuit of the 1960s? These texts tell of broader concerns, too. They reveal the ways cultures of sexuality and the ideas that accompanied them shifted from time to time and place to place. Local and global impulses intersected continuously after the war, and a popular queer literature came out of the UK and North America. By evoking this international literature, Webber, Pimley and Goodsell tied New Zealanders' experiences into their international context.1

These four unpublished texts took a kernel of homoerotic sensibility that dates back to the nineteenth century and made it self-aware. There are some interesting pieces of writing from the earlier period. "At the End of a Holiday," a story written by Masterton chemist Robert Gant and published in Sharland's Trade Journal in 1894, is full of allusions to male beauty and the homoerotic malleability of youth.2 Arch McNicol's story, "Mates Together," published in New Zealand Illustrated Magazine twenty years later, explores the ambiguities of mateship: two of McNicol's men "loved each other; although, perhaps, they were not aware of the fact." 3 "New Country," a 1926 play by expatriate Cantabrian James Courage, also teased out the ambiguities of male bonding, as did later pieces like Frank Sargeson's "The Making of a New Zealander," published in Tomorrow magazine in 1939.4 These early examples tell of intimacy and an erotic charge between men, but even though Gant, Courage and Sargeson took male partners in their personal lives, none of them induced homosexuality to speak on its own terms.

The terrain shifted slightly from 1930. That year, D'Arcy Cresswell, a poet born in Christchurch who had moved to London, published the first volume of his autobiography, titled The Poet's Progress. Cresswell followed it up with a second instalment, Present Without Leave, 
in 1939. He wrote of the affection between men that "so delighted the Greeks" and insisted that men's love for each other is superior to men's love for women. 5 Courage became bolder over time. His 1938 play "Private History" is set in an English boarding school and explores sexual and emotional relationships between the boys. 6 Homosexual themes in Courage's A Way of Love, from 1959, which tells of a relationship between an older and a younger man, caused the book to be banned in New Zealand. As writer Peter Wells puts it, A Way of Love was "like a rather beautiful fish glittering for a moment in the sunlight then submerging again in the murky depths."7 These years, though, saw the swimming of other fish-even if they were not quite as beautiful, glittery or controversial as Courage's.

Many authors regard the post-war decades - especially the 1950s - as a conservative time in New Zealand, the calm before the storm that was second-wave feminism and gay liberation. Michael King offered this type of account in his 1988 survey of New Zealand society after the war, but so too do the authors of more recent books. 8 Paul Millar's 2010 biography of writer Bill Pearson and the 2013 survey of post-war New Zealand culture by Jenny Carlyon and Diana Morrow, for instance, both portray these years as the epitome of puritanical conformity. 9 In fact, this time was more culturally complex than we might assume.10 There is no doubt the news media paid an increasing amount of attention to the growing queer cultures, and the 1950s saw a degree of moral panic over homosexuality in New Zealand. The Parker-Hulme murder in Christchurch, in which Juliet Hulme and Pauline Parker killed Pauline's mother with a brick wrapped in a stocking, was a flashpoint.11 Police began to pursue male homosexuality more actively - some used techniques of entrapment, especially in public spaces - even though the length of prison terms shrank and some men were released on probation as an alternative to jail.12 At the same time, a new confidence became evident.13 Men created their own cultures in a range of settings: parties, private drag shows, bars, unofficial same-sex weddings - and in writing as well. In New Zealand, as in the United Kingdom and elsewhere, the mid-1950s was a time of intense private and public contestation over the meaning of homosexuality.14

Raymond Williams's account of cultural change offers a useful framework for considering these complexities. Williams rejected the idea that culture takes a single form at a given point in time. Instead, he suggested that dominant, residual and emergent cultural forms intersect in any moment. Emergent forms of culture evoke "new meanings and values, new practices and relationships and kinds of relationship." 15 These slowly come into view, challenging dominant social arrangements quietly at first; and the slow decay of residual ideas points to the ongoing significance of older norms, conceptions and language. Williams's approach suggests we need not regard the post-war decades in New Zealand as either totally radical or stiflingly conformist. Instead, we might see them as a time of interplay between old and new ideas. In this way we can chart the political and cultural complexities, contradictions and shifts.

\section{De Profundis}

Imprisonment for male homosexual offences dates back to the nineteenth century: until 1893, only anal sex was illegal in New Zealand, but from that date all sex between men was punishable by law. The prison regime became more liberal during the middle of the twentieth century: flogging was abolished for all prisoners in 1941, and the regime of hard labour ceased in 1954.16 Incarceration gave rise to its own literature of a sort: some prisoners wrote notes and others penned short stories. Ernie Webber was one prison author. He was born in Dunedin in 1905 and grew up in the city. Later, he worked for the Trustees Executors and Agency Company, where he became Manager of Mortgage Securities. In about 1934 Webber moved to Auckland in order to pursue business ventures there, and he spent some time overseasincluding in India. In 1957, he was convicted of homosexual offences, newspapers widely 
reported the subsequent court trial, and the judge sentenced Webber to three years imprisonment. A further conviction for fraud caused his sentence to be extended, and he was finally released in 1962.

Historian Chris Waters writes that British psychologists became increasingly interested in homosexuality as a social problem during the early 1950s before turning to focus their attention on homosexual men as a social group.17 Some of their New Zealand counterparts evinced the same interest. In 1957, Mt Eden's prison psychologist asked Webber for his opinion on Oscar Wilde's long letter to Lord Alfred Douglas ('Bosie') written from Reading Gaol in 1897.18 Wilde's friend Robbie Ross later published that letter under the title "De Profundis," a Latin phrase that translates into English as "from the depths." Webber was happy enough to indulge the psychologist's curiosity, and he wrote a piece titled "De Profundis 1957" in three sections. The first part, titled "Oscar Wilde and Lord Alfred Douglas," contemplated the similarities and differences between Webber's own situation and Wilde's. "Both [cases] caused considerable public interest. In each instance the convicted parties had been subject to attempts at blackmail," Webber wrote.19 In Wilde's case, the Marquess of Queensberry's involvement is well known, and Webber implied he got into trouble with police after a business dispute withand an extortion attempt by - one of his associate directors: "evil of face and party to a struggle with the accused for control of properties."20

Two lovers made an appearance in Ernie Webber's own court case: an "easy going, intense and affectionate" sheep farmer named Stewart, and Webber's personal secretary Derek Douglas.21 Webber felt his relationship with Derek, on whom much of the newspaper publicity focussed, was very different to that of Wilde and Douglas. Webber saw the Irish playwright's relationship with Bosie as one-sided and corrosive, and he found "De Profundis" - in which Wilde excoriates Bosie for his shortcomings - to be profoundly dispiriting evidence of an "illfated and lamentable friendship." Bosie frequently had "fits of almost epileptic rage," Wilde wrote, and the "unintellectual friendship ... entirely dominate[d] my life." He added: "While you were with me you were the absolute ruin of my Art." 22 "The tragedy," Webber wrote in his diagnosis of Wilde's life, "was the parasitic involvement proved inescapable and brought complete destruction."23

But this was not Webber's own experience with Derek, the figure the prison psychologist presumably regarded as Webber's own Bosie. Webber compared the two relationships: "[T]he circumstances of Wilde and myself were very superficially alike, and ... merely because of a trial about the same problem such resemblance went little further than that a leading witness in both cases had Douglas for a surname."24 Instead, in Webber's case,

[n]ever was a friendship so complementary in character. Cooking, house management, laundry, keeping a car in order; all those things Derek excelled in and liked. We lived well. The same parallel cause ran its smooth way in business. Derek was a competent typiste, book keeper and records expert. 25

Derek Douglas was, in Webber's words, "the invert private secretary, intelligent, competent, affectionate, temperamental in a mild way, and the loved one of several thousand nights and more."26 In comparing his own relationship to Wilde's, Webber could not have been more emphatic: "Everything that Lord Alfred Douglas was to Wilde, Derek Douglas was not to me." Instead, Webber's and Douglas's friendship "moved into the deepest attachment. One [I] will never feel again for anyone else." 27 At the trial, Derek stood up and testified about his love for Ernie Webber.28 Unlike Wilde, Webber had no regrets about his own relationship with Derek, and "Not one word of criticism of my companion have I to record." 29 
In the second part of "De Profundis 1957," subtitled "Time of Trial," Webber provided further details of the circumstances surrounding his own arrest. He rather grandiosely claimed his was "the most famous homosexual trial in the annals of New Zealand's Supreme Court history."30 His account contains some themes familiar to those who knew about the Wilde case, including the ways the media and court testimony described a homoerotic life characterised by decadent extravagance-decadence, even. "In this trial," Webber wrote of his own lavishly decorated business offices, "the Crown intended and deliberately presented to the jury the business premises as the sybaritic background of debauchery of an Arabian Night's extent."31 Webber went on floridly: "Tea room whispers, coffee shop innuendo and beer parlour comment assured all listeners the trial was as spicy as a curry from Hindustan, lush as a tropic night." 32 Even though Webber concluded his relationship with Derek was much more fulfilling than Wilde's and Douglas's, by describing the Crown's depictions in this way he evoked this residual thread of connection with the events of 1895 .

"The Green Gold" is the third part of "De Profundis 1957." This poetic, moody account tells of travel through the central North Island, an area Webber had extensively explored when he was younger. In "the shadow of Mt Ruapehu," he wrote (placing himself in the third person): At this small village the Teller of Tales has spent many delightful weekends in its backwood surroundings of utterly silent nights, broken only by passing non-stop expresses roaring through the dark and of days by the river-sides fishing, or on a picnic, or merely laxin [sic] away some hot morning upon the rolling tussock-covered foothills. Maybe perhaps, in strolling through the forests of totara, rimu, matai, and kahikitea.33

While Webber had lived in "immense cities like Hong Kong, Shanghai, Canton, Calcutta, Bombay, New Delhi, Sydney and others," and "savoured each and all to the full," it was the North Island's "exuberant forests" and an "apparent immobility and quiet at times" that stirred a spiritual feeling in him. In this context he referred to the ancient Greeks, "the sacred Delphi" and the "awesomeness of the divine." The Delphic shrine is located on Mt Parnassus where the Greek God Apollo uttered prophesies through his priestesses. For Webber, though, sacredness resided in the landscape of central New Zealand, a "land of trees and rivers and ... sacred mountains, 'the three Tongariros of Tuwharetoa Tribe."'34 The isolated spaces of the central North Island represented, for him, an escape from the strictures of social expectation and respectability.

Webber's mixture of New Zealand and ancient Greek themes echoes the later sections of Wilde's "De Profundis." These indicate how homosexual New Zealanders tapped into some of the same themes as their international counterparts and sometimes imbued them with a local flavour. Wilde adopted Jesus Christ as a symbol of human kindness, and although Webber gestures towards Christ with his language- "backwood surroundings of utterly silent nights" is one example - the landscape, with its sacred importance to Maori, is the key to his own spirituality. Still, Webber's "De Profundis 1957 " is a fascinating coming together of themes drawn from a wide international repertoire. When Webber discussed the relationship between Wilde and Douglas he compared it - unfavourably — to the attachments between biblical and classical lovers: "It went with no such amalgam as united David and Jonathan. Or Damon and Pythias." Wilde, Webber added, "went down the road to the Christian hell." 35 These themesthe religious, the classical and the homoerotic - had a long association internationally. Eighteenth-century German art historian Johann Joachim Winckelmann-among othersdrew inspiration from the connections between classical imagery and same-sex desire, and Greek society held a fascinating for many men during the late nineteenth and early twentieth 
centuries.36 Such themes had a long lineage and provided reference points here and overseas. 37

Similarity and difference gave way to one another in the New Zealand context. If Webber contrasted his own situation with Wilde's, he did not totally distance himself from the playwright. Wildean events and styles had residual importance, and the traces were clear in Webber's writing. Chris Waters suggests homosexual English men of the 1950s often put as much space between themselves and Wilde as they could; not until the 1970s would the playwright be seen less as a "toxic commodity to be avoided at all costs" and more "a resistor, a means of attacking sexual moralism." 38 This was not necessarily true of New Zealand, as another example shows. In 1923, a friend of James Courage pledged his loyalty: "I still remain faithful to Oscar ... people may say what they like."39 Webber's act of writing of a piece titled "De Profundis 1957," his lack of hostility to Wilde per se, and recognition of the similarities between his own trial and Wilde's all suggest Webber also identified with the playwright's life to some extent. Did the geographical distance from Great Britain help to defuse the opprobrium that Waters observes in the British context? Perhaps. Whether they adored Wilde or were wary of his life, New Zealand men found him a valuable reference point.

\section{The Rock Orchid}

"The Rock Orchid" is a 170-page manuscript novel written in Mount Eden during the early 1960s. Its author, Bert Pimley, was a friend of Ernie Webber, and Webber tried — and failedto help Pimley publish it.40 It is remarkable the manuscript even survived, as prison officers destroyed one copy. Fortunately, a duplicate was successfully smuggled out of the prison.41 A number of pencil sketches illustrate the story, although the identity of their creator remains unclear: he may have been Pimley or one of the other inmates.

The novel is based on real life: as Pimley notes, it "so closely follows fact it is difficult to decide where fact ends and fiction begins." 42 "Rock Orchid" tells the story of Berne Pintalpresumably a thinly disguised masque for Pimley-who joined the army during the Second World War, served time in the Pacific, worked a few different jobs back home in New Zealand, and was jailed for three years, at the age of thirty-six, for safe-cracking. The novel begins by laying out this background, and each subsequent chapter deals with a specific theme in the daily life of the prison: gambling, tattooing, concerts, putting up the Christmas tree, complaints about prison food, reading, and writing. Some prisoners composed their autobiographies while others wrote letters on toilet paper and dispatched them to Mt Eden's 'female division' by throwing them over the fence in tennis balls. 


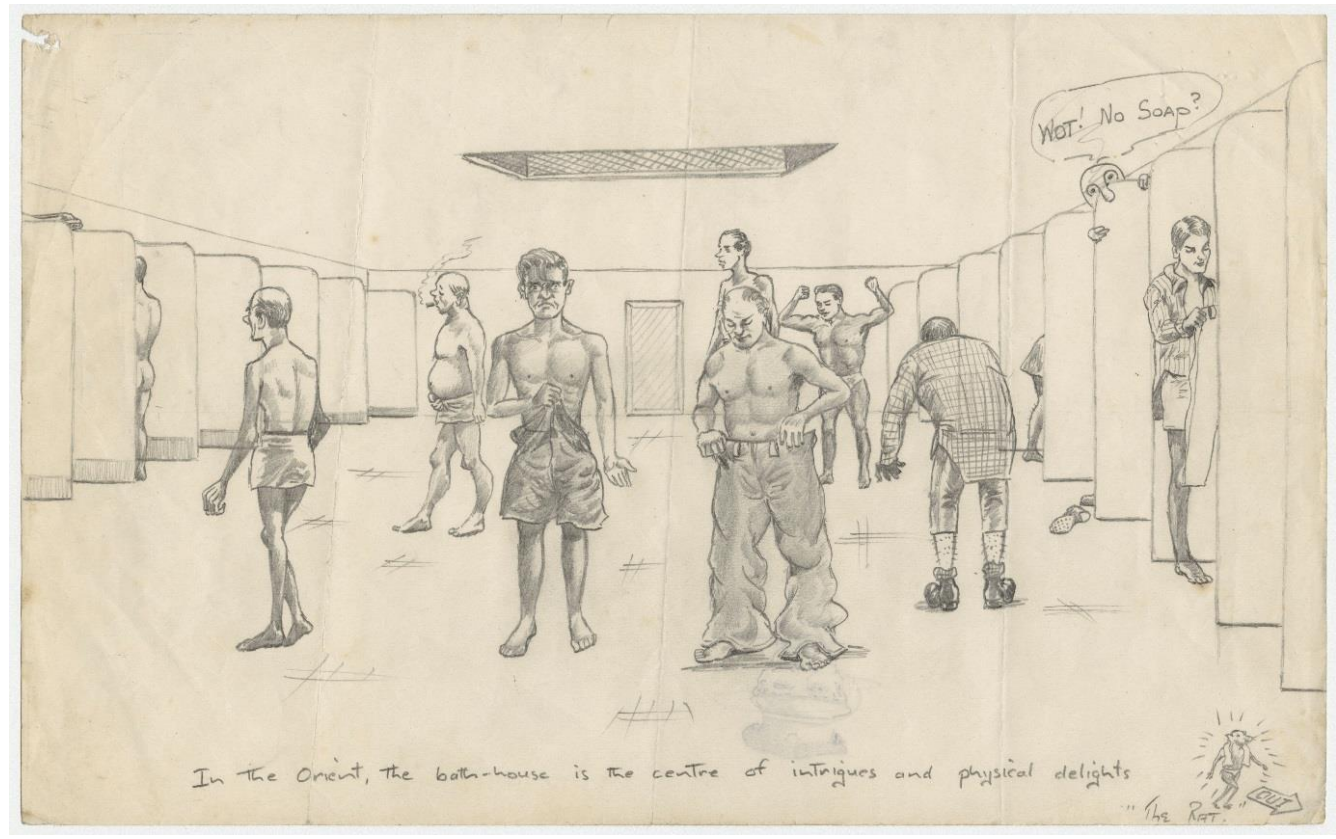

[Figure 1: "In the Orient, the bath-house is the centre of intrigues and physical delights." Bathing is one daily prison ritual that appears in the sketches that accompany "Rock Orchid." S18-513d, MS-3333/198, Hocken Collections.]

Details of the intimate relationships between men weave through these thematic chapters of "Rock Orchid." Pimley describes some of those involved in feminine terms. These include a fellow called Polly: "There is definitely something the matter with his hormones." 43 Another is a "Floozie" and "a willowy wench."44 Not everybody with homoerotic interests was such an "obvious type," though. Dummy was one of the more conventionally masculine men; he arrived at Mt Eden after he enticed "two schoolboys into bed with him" and was caught.45 Other prisoners proved to be more incidental in their homoerotic attachments. One day, playing cards, a group of inmates "had no money or tobacco to play for, so we played for roots."46 Twentieth-century prison culture blurred the lines between those men who preferred other men in their civilian lives and those who preferred women: the segregated context induced some in the second group to have sex with other men during their imprisonment. 47 "This place breeds them," Pintal said.48

One particular relationship occupied Pintal's time: his own liaison with nineteen-year-old Mel Tipu. This young man ran into trouble at the age of twelve; after having sex with other boys he was admitted to the Boys' Home in Levin. He ran away and was sent to Waikeria Borstal where he "flitted from one affair to another."49 Once again Tipu escaped, and once again he was captured: this time he ended up at Mount Eden. Tipu possessed a magnetism that attracted the other prisoners; as he said to Pintal, "I can't help it if these blokes love me."50 Pintal soon succumbed to "the strange magnetic powers of the lad," and each of Pimley's early chapters concludes with a brief description of an encounter between Pintal and Tipu.51 Pimley wrote about their first time. "To Berne, this was a revelation. A revelation as marvellous as it was horrible. They were the whole Apocalypse at once, angel and beast, plague, lamb and whore in a single devine [sic], revolting, and overwhelming experience."52 The second sexual experience was rather more romantic in tone. "The only beating was the throbbing of their hearts, as together they found bliss in a world that had become beautiful and rich and benevolent out of all recognition."53 Pimley hinted that the pair could transcend-if only 
temporarily - the harsh world of the prison: "their intimacies of almost unreal delight carried them away on a cloud."54

As a piece of writing, "Rock Orchid" gave voice to a complex set of ideas about homoeroticism. The language of revulsion belonging to dominant social norms: the phrase "abominable, detestable crime of sodomy," for instance, had appeared in court proceedings and newspapers since the nineteenth century.55 On the other hand, the use of spiritual language and imagery to evoke same-sex love dates back to the eighteenth century when the intensity of love for one's partner was sometimes framed in terms of a love of God.56 Another of Pintal's passages"They changed a mere suggestion [to have sex] to a divine ecstasy, and promoted it from the rank of a disease to that of a true and natural form of love" - ties together a range of tropes.57 These all jostle for attention: the older idea about divinity, the late-nineteenth-century notion that homosexuality might be considered a disease, and the more resistant idea that love between men was "natural." Tipu was not quite sure how to account for his desires, although he suggested they were inherent in his being. "I can't explain. It's just something that's there, inside," he said, echoing an essentialism that appeared in some nineteenth-century psychiatry.58 Like Webber, Pimley reached even further into history and evoked the ancient world. "The vogue of homosexuality seems to have been universal in the Hellenic world [and became] a particular fashion in love," Pintal told his readers near the end of the manuscript. "Convention and public opinion moulded the material of love into forms which a later age has chosen to call unnatural." 59

"Rock Orchid" also showcases some of the slang circulating at the time. This slang, in turn, encodes contemporary social norms. Pimley reveals an assumed malleability of sexuality when he puts these words in Pintal's mouth: "I used to hate these fellows, now if this boy gives me a break I'll be one of them."60 Sometimes, Pimley suggests, the repetition of homosexual activity brands its participants in particular way. For instance, Pintal said to Tipu: "You're going to tell me I'm a homo myself. Sure, for the past few months I've been shagging you. So that makes me a fruit. But that doesn't mean I've got to trail around after everything that wiggles its hips."61 Other norms make an appearance too. Pimley refers to the implicit-but not always maintained-monogamy of some prison relationships when he writes that Frank "was married to Sonny" and that Pintal became jealous when he suspected Tipu was "shagging" Joe, another prisoner.62 The general idea that a young prisoner belonged to an older inmate - at least for a time - dates back to the early twentieth century.63 Pintal turned to Tipu and said: "I've loved you for months, you little tramp, yet you flop in the sack with all the punks and queers in the place."64 ("Punk" is slang for a young, small or unconfident prisoner.) 65 Other terms say less about sexual classifications as they evoke sexual interactions in distinctly antipodean terms: "Do you feel like a root?" Tipu asked Berne, and two chapters later he declared, referring to the prison officers: "no screw is climbing me."66 


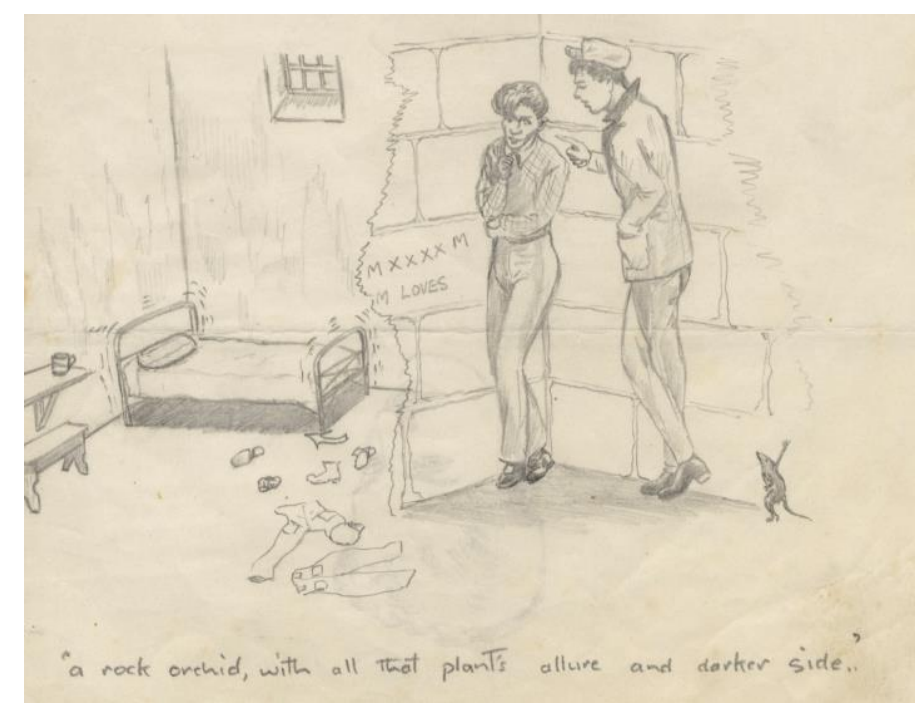

[Figure 2: "A rock orchid, with all that plant's allure and darker side." In the cells of Mt Eden; the slight young man with the curly hair is Mel Tipu. S18-513a, MS-3333/198, Hocken Collections.]

If the narration of Berne Pintal's and Mel Tipu's affair told of the linguistic constructions of homosexuality, then the account of their relationship's ending evoked the mid-century New Zealand city, the disappointments - and perils - of dying love, and the literary genres of the time. In Chapter 14 we learn that the couple are to be released within two days of one another. Pintal could hardly wait. He and Tipu would be free "to drink together, eat together, and sleep together. The world was indeed a pleasant place."67 Berne walked through the gates first, and he relished the world outside. A contact arranged a car for him, and another got him a gun. He drank in bars and breakfasted in hotels where he "sat at a table covered with a crisp, starched cloth, the silver gleamed, and people chatted to each other in a light-hearted, care-free way."68 When he arrived at the prison to pick up Tipu, though, the lad had gone. He had been released a day early, having spent the morning running down Pintal to the other inmates. "Like the epiphytic orchid," Pintal concluded after speaking to another ex-prisoner, "Tipu had simply used him as a host."69 Nevertheless, he set out on a road trip to find the young man. Eventually, Pintal ran into Tipu in Dunedin:

"Mel Boy, how are you doing?"

"Mel Boy ... Don't Mel Boy me ... you dirty mug. What's the big idea, following me about?"

"Sure Mel, I've been looking for you. What happened in Auckland?"

Mel leered drunkenly at Berne. "In Auckland? Pretty obvious, isn't it? I ... I just didn't want any more to do with you. I..."

"But you wanted me once."

"I can change my mind, can't I? I don't want you, or any part of you-is that clear enough, or shall I draw you a diagram?"

Berne's hand tightened on the .38. "But you said ...."

"Frig what I said. You were around. You got what you wanted. You gave me things I wanted. So what? Just get lost will ya? Go take a running jump at yourself....”70

This carried on for a while. Berne saw red when Mel revealed he was waiting for a client name Joe: 
Berne swallowed hard. Pulsing veins pumped on his forehead. So this was the end of the road. All he could see was a sneering contemptuous face gazing back at his own. This did not make sense; this sloe-eyed youth whom he loved and who in turn had professed his love for Berne, now mocked him — nothing made sense - a male prostitute, a-71

Berne pulled the trigger, with fatal consequences. "Mel died at the first shot. The insolent smile vanished-his eyes grew wide in apparent astonishment."72 Berne stood, rooted to the spot, waiting for the police sirens.

The final pages of "Rock Orchid" offer a heady mixture of literary influences, and these tell of a New Zealand gay writing culture shaped, at least in part, by international trends. Berne Pintal's travel around the country looking for Tipu, and the subsequent murder, combines at least three impulses. The first is the beat generation literature exemplified by Jack Kerouac's novel On the Road, in which the protagonist, like Pintal, travels around the countryside in a melancholic manner. ("Berne spent the day moving from bar to bar, pool-room to pool-room, in his search for Tipu.")73 The second is the Mickey Spillane-style gangster thriller where the protagonist kills his captors. The third is the mid-century gay pulp novel in which the protagonist dies - or, in a kind of existential death, turns straight.74 Gender studies scholar Michael Bronski suggests pulp fiction was preoccupied with outsider status, "heightened emotions, violent actions, and eroticized behaviors, all of which take place in a demi-mode, often criminal, social milieu that is firmly outside of middle-class stability and respectability."75 These pulp impulses are visible in Bert Pimley's account of queer life in and after Mt Eden.

"Rock Orchid" represents prison homosexuality in complex social, spatial and political terms. Like Webber's "De Profundis 1957," it took shape during a period where international gay literature — of which more shortly_-proliferated alongside the broader pulp literature. "Rock Orchid" revealed residual cultural forms and gestured to its own time by voicing beliefs about the naturalness of homosexuality. By articulating men's resistance to prevailing sexual norms, it looked forwards towards the gay liberation movement.

\section{The Night is Young}

Not all mid-century gay writing was concerned with imprisonment, its social patterns and consequences. Some authors told of the growing inner-city cultures. Auckland man Don Goodsell produced two stories, both based on the lives of real people. These remained unpublished, but men passed multiple typescript copies from hand to hand. My own copies come from two Dunedin men with connections to Auckland. Written in 1966, "The Night Is Young and We're So Beautiful" is almost certainly named after the 1945 Frank Sinatra hit "The Night is Young (And You're So Beautiful)," and it begins like this:

July 1966. The crowd has clattered up the stairs to Lindsay's flat, the gram has been switched on and "I Left My Heart in San Francisco" is blaring forth, drinks are being served in the kitchen and another Saturday night of fun and frolics has begun.76

This is the story of Lindsay and Lennie, friends since high school, artists of advancing years who hold regular Saturday night soirees at home in Auckland. Private parties were popular among the gay crowd after the war, and groups of men often socialised with their friends there. The first part of the story sets the scene, and the décor rates a mention. There is "a dresser displaying a silver tea-service," "a set of bookshelves crammed with art books and novels," and a Van Gogh painting of a young man on one wall. Goodsell also tells his reader about the characters that inhabit the party - the regulars are referred to as "the Group" - and their banter. 
Highly tasteful domestic space alternates with drunken dissipation. "Oh, excuse me, I AM getting common, aren't I deyah!"' one man exclaims after several Bacardis. Doug, also known as Kitty, reacts to a spilt drink: "Oh Peter, you clumsy bitch! Next week I'll leave you at home and bring [the pet pedigree poodle] instead — at least he's a good conversationalist." Visitors from out of town, or those new to the scene, are welcomed and appraised:

The crew-cut young man by the table steadies himself.... He is wearing tight beige shorts cut as briefly as possible, with white sox between scuffs and nicely shaped calves - all the better to show up the deep tan of his legs which it has to be admitted are very attractive legs, a fact always noticed by the Group.

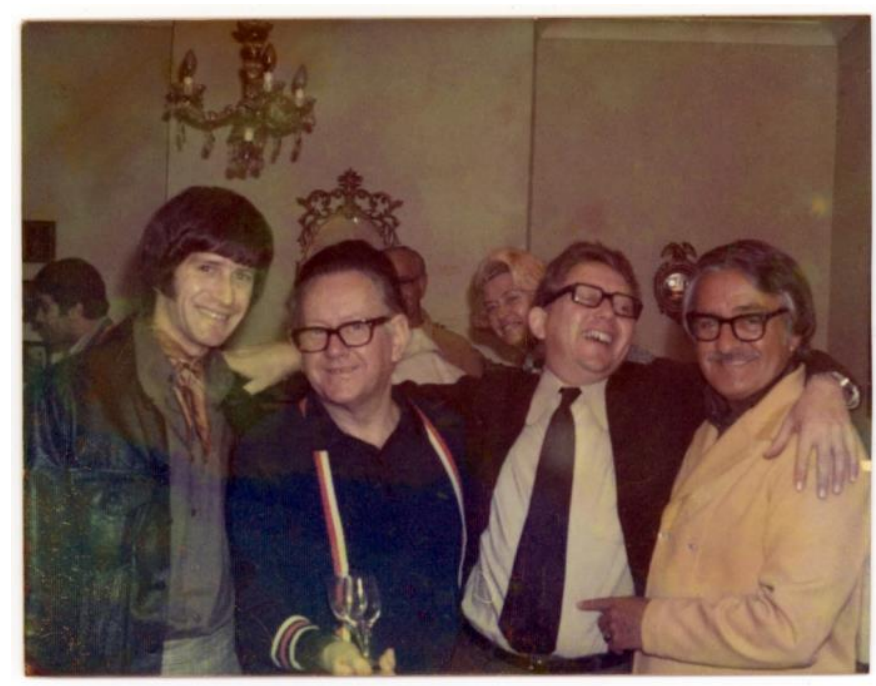

[Figure 3: A 1960s gay house party in either Wellington or Auckland, complete with tasteful decorations. Author's collection]

Newcomers learned to negotiate the rules of taste, sociability and erotic interaction, elements that constantly intersected in parties like these. One novice worried he "ought to say something smart and sophisticated," and many of his companions would have expected it - even if, at this moment, sexual attraction came to the fore:

John realises there is someone on his other side coming to his rescue; it is the terribly square-looking one in shorts. "Oh no, I've never been up here before." The other's brown eyes flicker with interest. John immediately worries that he ought to say something smart and sophisticated like they do in the movies. He tries "what a perfectly delightful room. I adore that van Gogh, don't you?" The kind brown eyes sweep over the heads to the far wall. "Mmmm. I always think that young man is real sexy looking. Wonder how many times Alan had him!" John blanches slightly; he is not used to quite such open references to anyone's attraction to his own sex.

For many men the pub-which closed at 6 o'clock — was the portal to the party, and Goodsell narrated the timeline of events in his campily astute way:

[Men went] straight from an hour or so's drinking at the pub with the attendant frantic jockeying for an invitation to, or at least the address of, a party to occupy the later stretches of the evening and to supply the possibility of finding a partner for the night. Whether or not this was accomplished satisfactorily, they would spill out onto the footpath at 6.15 , ejected by the bells. But far from dejected belles, they would continue to pick up sides for the evening or, if still a neophyte in their world, cast out dazzling smiles and radiate such good humour as to prove irresistible. 
With a degree of trepidation, "neophytes" like John looked forward to learning about the gay life, and entering into a world that provided friendships, sexual opportunities and partners:

John found himself at six-fifteen getting into a large old car with a crowd of the bar's habitués and being swept off to a party! Still, he wasn't likely to meet anyone from Varsity here and it would be something to tell that so-called friend who had ditched him for that lovely blue-eyed sailor, not that he could blame him.

John, Goodsell tells us, had "only this week decided to take the plunge and find the Real Way of Life for himself." Others drifted in and out of these queer circles, and not everyone took the same approach to the intersection between the public and private worlds. Some men worried about what the world thought of them, but others simply did not care:

The more discreet or nervous would exit hurriedly and linger not. They would attempt an air of "How ever did I get mixed up with this lot when I was really drinking in the side bar with all those butch sporty types?", and rush to their transport looking neither to right nor to left. However most of the crowd, having ceased to care after half-adozen or so drinks what the world thought of them, would go on loudly making assignations for later, arranging liaisons, or merely settling the more immediate business of who's travelling with whom, then pile into cars and race to various havens around the city to continue their merrymaking until it came time to think of the more serious matters of the night.

"The Night is Young" gestures to the kinds of international connections common among men during the 1960s. Steadily improving air links made the trans-Tasman interchange increasingly popular, and Sydney was portrayed as an exotic locale in which even the most reticent New Zealanders might enjoy themselves. A character named Jack, who was rarely sexually active in Auckland, made the most of his holidays to Australia:

Of course the stories of what Jack gets up to in Sydney are amazing if we are to believe what he says. The number of Beautiful People (usually, perhaps necessarily, of considerable means) who have pleaded with him to stay forever would form a tidy Group of their own. "I'd go and live in Sydney like that" he professes with a snap of his fingers, "but of course at the moment I've far too many responsibilities here."

Goodsell's story speaks of a social world both constrained and exuberant, characterised by strong social bonds as well as a wariness about the consequences of breaching the norms of social respectability. Some of the Goodsell's men are happy to leer up in the street-and cruise the city's public spaces - but others, like Stephen, are "too nervous to go on the prowl. Working as a lawyer, he is conscious that Auckland is a very small city, that at any time some unwanted person can be breathing down your neck about to reveal one's secret life." Still, Lindsay and Lennie's party was a good place to meet others. Stephen "became at last one of a group in which he felt completely at home, accepted for himself." The 1960s gave rise to an increasingly influential discourse of discovering and being "oneself," and the party — and "the Group"was Stephen's route to self-actualisation.

"Did You Ever See a Dream Limping?" a title presumably modelled on the name of the 1933 song "Did You Ever See a Dream Walking," was Goodsell's second story.77 It reads less like a documentary and more like a piece of fiction, and it has a clear plot. Like "The Night is Young," it begins with a house party. "They had all been drinking liberally; the atmosphere was one of unrestrained hilarity," Goodsell wrote. Protagonist Stephen met a chap named Glen, a lumberjack from the state forests at Kawerau. After a while, members of "the Group" decided 
to move on to another party in Ponsonby, then a less salubrious part of Auckland. "Why Kitty wanted to leave her comfortable mansion for some doubtful dive in one of the lowest areas of town wasn't clear," Stephen wondered.

Stephen and Glen hit it off - they kissed, and Stephen "emerged quite dizzy" — and shared a car to the second party. Glen sat next to Stephen and "kept squeezing his knee," but then things started to go wrong. The driver got lost "in the wilds of Herne Bay," and Glen hopped out of the car to see where they were. He somehow ended up on the bonnet of the car parked behind. "'Jesus, I've nearly done for meself' he moaned, rubbing his backside. 'I jumped on the bonnet of that bloody Jag and the fucking thing on the radiator went right into me arse!" A trip to the casualty ward of the hospital followed; it turned out Glen had lacerated a tendon. Although he and Stephen repaired to a hotel room and shared a bed-another couple had a second bed in the same room - they would not get to "assuage their apparent passion." Stephen was disappointed: it may have been "an ugly-looking blemish but on a delicious looking buttock, lean and smooth and creamy white against the tan of the appetising rest of Glendon." But it was not to be. "Jesus, what a night. I'm buggered" grunted Glendon as he slid into bed and fell asleep. Stephen "lay there listening to the night sounds of the hotel and from the nearby railway yards" before getting out of bed and heading home. He escaped into the corridor; "Bogart could not have escaped more stealthily to his car."

"Did You Ever See a Dream Limping?" is an evocative and humorous story, a tale of homoerotic sociability and desire in a rapidly changing New Zealand society. The fine grain of everyday gay life rubs shoulders with a number of more specific themes: fantasy worlds, shifting engagements with urban space, and the ongoing rise of the car in New Zealanders' social lives. There are encounters between rural and urban, too: the lumberjack and the city slicker. At the same time, "Dream Limping" has echoes of the new gay literature imported from overseas. Bronski estimates that three hundred books with gay male themes were published between 1940 and 1969.78 John Rechy's City of Night, from 1963, is one wellknown example. In City of Night, an older man says to a younger one he has just picked up: "that streetll swallow you so deep you wont know where you got sucked in, and it wont even throw you up like bad beer, itll digestya."79 The slang in "Dream Limping," and the register in which it is embedded, resembles the writing in City of Night. In "Dream Limping" Stephen and Glen interrupted their roommates in the middle of "somethin' important," and one says 'Hey, watcha doin'-." The American influence on amateur New Zealand writers is unmistakable.

It is hardly surprising gay New Zealanders-Pimley, Goodsell and probably others-tried their hand at adapting overseas genres to their own uses. Many were avid readers of the foreign books. Some were sold in shops, and others came into the country in the luggage of ships' stewards and airline cabin crew who had connections in both international and local queer communities. Goodsell would have been an avid reader: an arts and law graduate, he went on to work in the Auckland University library. Other local men were just as enthusiastic. David Wildey, a school teacher and artists' model who lived in both Auckland and Christchurch, kept a diary with an extensive reading list: works by André Gide, Gore Vidal and James Baldwin feature alongside Rechy, Jean Genet and Christopher Isherwood. James Barr's Quatrefoil from 1950, well known for its positive portrayal of homosexuality, is on the list, as are older books whose titles hint at their less sympathetic approach: Ernest Milton's To Kiss the Crocodile from 1928 and André Tellier's Twilight Men from 1931.80 Those who wanted to read and write about their own culture during the 1950s and '60s certainly had the means to do so. 


\section{Conclusion}

Bronski rejects the common-but misguided-perception that "homosexuality was largely unspoken and unseen" during the 1950s. "Nothing could be further from the truth," he adds, suggesting that popular culture offered increasingly sexualised portrayals of both men and women.81 To cast this observation in Williams's terms, residual and dominant cultural impulses were being strongly challenged by the emergent ones that grew in prominence over time. Bronski writes in the American context, of course, but what about New Zealand? Peter Wells suggests that the period between James Courage's (suppressed) novel A Way of Love and the new gay writers of the early 1980s seemed to be nothing but "an eternity of blank." 82 In one sense this is an apt observation: local readers depended on the wave of imported literature rather than books written here. But this does not mean men were not writing, even if they did so only for themselves and their friends. Their efforts were possibly not great literature - although maybe it is not for the historian to say-but still they offered opportunities for self-expression and a mode of resisting the idea that only judges, police officers and newspapers should speak on the subject of homosexuality. In this sense, they were important examples of an increasingly self-aware and well-networked gay culture.

Even though they had very limited distribution, these texts provide the twenty-first-century reader with a wealth of detail about the sexual and social cultures that men crafted in a range of spaces: prisons, streets, homes. They catalogued shifting linguistic conceptions, too, giving voice to both residual and emergent forms of expression. Webber described his lover Derek as an "invert," drawing on a term popular at the start of the twentieth century to describe a man with the desire of a woman (that is, directed toward other men). "Queer" had become a commonly used label during the 1940s and this term appeared in "The Rock Orchid." "What? Chenry? Is he a queer?' Pintal asked. Mel nodded." 83 Other descriptions crop up there too: "floozy," "fruit," "punk" and "homo." These became common in the years that followed.

Webber, Pimley and Goodsell wrote their stories over a ten-year time span, but the unevenness and dynamism of social change, as well as a range of available literary genres, are evident during this period. Webber's piece made constant comparison with Wilde's "De Profundis" and its mentions of the classical world also turn up at the end of "Rock Orchid." Ancient Greece made no appearance in Goodsell's 1960s stories, though. These tell about modernity, and their reference point is big city social life, a growing gay community, and an erotic style that echoed the new gay fiction. Pimley nodded towards the moodiness of Kerouac's work, but Goodsell's writing was rather more reminiscent of Rechy's. There are subtle differences between Goodsell's tales, too. The men in "The Night is Young" enjoyed a drink while 1930s music fills the living room, but those in "Dream Limping" found themselves "shouting over the Beatles in a vain effort to make themselves heard." These stories tell of the interplay between residual, dominant and emerging cultural forms, documenting swiftly changing modes of socialising and self-expression.

It is unsurprising, then, that desire appears in these texts in very different ways. "De Profundis 1957" stresses the companionship of Ernie and his lover Derek, a relationship between an older and a younger man that is implicitly compared with Damon and Pythias, heroic friends from Greek history. Webber saw friendship as "the deepest attachment," and his appeal to pure friendship reprises Wilde's insistence that a "deep, spiritual affection" connects men most profoundly.84 Wildean conceptions were reduced to residual cultural forms by the 1950s, even though the status of Wilde as a homosexual hero would ramp up during the 1970s. The prison writers had a variety of takes: Webber regarded homoeroticism as something suppressed by the state, but Pimley portrayed sex as transcending the state's attempts to control it. Meanwhile, 
homoerotic desire unashamedly bubbles to the surface in Goodsell's "Dream Limping"- even if a tendon injury stops Glen and his new friend from actually having sex. For Goodsell, physical attraction crackles away in the living room, in a car, in the kitchen of the party in a then rough, now gentrified, part of Auckland.

These post-war urban gay cultures would, in time, would play an important role in the decriminalising of male homosexuality. Concerted attempts began with the Dorian Society's legal subcommittee of 1962, an early homosexual law reform initiative established in Wellington right in the middle of the period represented by Webber's, Pimley's and Goodsell's writing. This later became the Wolfenden Association and then the New Zealand Homosexual Law Reform Society.85 These four examples of homemade literature were produced in a surprisingly dynamic time in New Zealand's history, and even though no one ever published them and they were seen by relatively few they stand as interesting-if obscure- - sentinels in the rapidly changing social and political world of gay men. 86

\footnotetext{
${ }^{1}$ Miles Fairburn, "Is There a Good Case for New Zealand Exceptionalism?" in Disputed Histories: Imagining New Zealand's Pasts, ed. Tony Ballantyne and Brian Moloughney, 143-168 (Dunedin: Otago University Press, 2006).

${ }^{2}$ Robert Gant, "At the End of a Holiday," Sharland's Trade Journal, 7 July, 1894. For a discussion of this story see Chris Brickell, Manly Affections: The Photographs of Robert Gant, 1885-1915, 134-138 (Dunedin: Genre, 2012).

${ }^{3}$ Arch M. McNicol, "Mates Together," New Zealand Illustrated Magazine, 1 May, 1905, 96; see my analysis in Chris Brickell, Two-by-two: Men in Pairs (Dunedin: Genre, 2013).

${ }^{4}$ James Courage, "New Country," Oxford Outlook 8, no. 3 (1926), MS-0999/131. See Christopher Burke, "Introduction," in New Country: Plays and Stories, by James Courage, 9-30 (Dunedin: Genre, 2015). For a good analysis of homoeroticism in Sargeson's writing see Peter Wells, "Introduction: Modest Achievements," in Best Mates: Gay Writing in Aotearoa New Zealand, ed. Peter Wells and Rex Pilgrim, (Auckland: Reed, 1997).

${ }^{5}$ D'Arcy Cresswell, The Poet's Progress (London: Faber and Faber, 1930), 40-42; D'Arcy Cresswell, Present Without Leave (London: Cassell, 1939), 231.

${ }^{6}$ Transcript of James Courage, "Private History," MS-0999/001, HC.

${ }^{7}$ Wells, "Introduction," 25.

${ }^{8}$ Michael King, After the War: New Zealand Since 1945 (Auckland: Hodder and Stoughton, 1988), 45.

${ }^{9}$ Paul Millar, No Fretful Sleeper: A Life of Bill Pearson (Auckland: Auckland University Press, 2010), 253; Jenny Carlyon and Diana Morrow, Changing Times: New Zealand Since 1945 (Auckland: Auckland University Press, 2013), passim.

${ }^{10}$ Bronwyn Labrum, Real Modern: Everyday New Zealand in the 1950s and 1960s (Wellington: Te Papa Press, 2015). I also offer a detailed analysis of the complexity of these decades in Chris Brickell, Teenagers: The Rise of Youth Culture in New Zealand (Auckland: Auckland University Press, 2017), chapter 5.

${ }^{11}$ Alison Laurie and Julie Glamuzina, Parker and Hulme: A Lesbian View (Auckland: Women's Press, 1991).

${ }^{12}$ Chris Brickell, Mates and Lovers: A History of Gay New Zealand (Auckland: Godwit, 2008), chapter 5 .

${ }^{13}$ Chris Brickell, "Moral Panic or Critical Mass?: The Queer Contradictions of 1950s New Zealand," in Queer 1950s: Rethinking Sexuality in the Postwar Years, ed. Heike Bauer and Matt Cook, 94-114 (Houndmills: Palgrave, 2012).

${ }^{14}$ Richard Hornsey, The Spiv and the Architect: Unruly Life in Postwar London (Minneapolis: University of Minnesota Press, 2010), 26. On the debates around decriminalisation in the UK, see Brian Lewis, Wolfenden's Witnesses: Homosexuality in Postwar Britain (Houndmills: Palgrave, 2016).
} 
${ }^{15}$ Raymond Williams, Marxism and Literature (Oxford: Oxford University Press, 1977), 123.

${ }^{16}$ Dick Morrison, “Anti-gay Laws Have Long History in New Zealand,” Socialist Action, 12 July, $1974,5$.

${ }^{17}$ Chris Waters, "The Homosexual as a Social Being in Britain, 1945-1968," Journal of British Studies 51, no. 3 (2012): 690, 697.

${ }^{18}$ Rupert Hart-Davis, ed., Selected Letters of Oscar Wilde (Oxford: Oxford University Press, 1979 [1962]).

${ }^{19}$ Ernie Webber, Typescript, MS-3333/184, Hocken Collections (HC).

${ }^{20}$ Webber, Typescript, 11. For an account of the Wilde trial and its wider context see Morris Kaplan, Sodom on the Thames: Sex, Love, and Scandal in Wilde Times (Ithaca: Cornell University Press, 2005).

${ }^{21}$ Webber, Typescript, 12.

${ }^{22}$ Hart-Davis, Letters, 153, 154, 156, 158.

${ }^{23}$ Webber, Typescript, 5 .

${ }^{24}$ Webber, Typescript, 7.

${ }^{25}$ Ernie Webber, "De Profundis 1957 Part II," Handwritten manuscript, MS-3333/361, HC.

${ }^{26}$ Webber, Typescript, 12.

${ }^{27}$ Webber, Handwritten manuscript.

${ }^{28}$ Webber, Handwritten manuscript.

${ }^{29}$ Webber, Handwritten manuscript.

${ }^{30}$ Webber, Typescript, 9.

${ }^{31}$ Webber, Typescript, 11.

${ }^{32}$ Webber, Typescript, 11.

${ }^{33}$ Webber, Typescript, 15.

${ }^{34}$ Webber, Typescript, 16.

${ }^{35}$ Webber, Typescript, 6.

${ }^{36}$ Robert Aldrich, The Seduction of the Mediterranean: Writing, Art and Homosexual Fantasy (London: Routledge, 1993).

${ }^{37}$ Webber also wrote other manuscripts with gay themes, although these are beyond this article's scope. One was titled "Aslan: A Strange Indian Love Story," from 1964: MS-3333/185, HC.

${ }^{38}$ Chris Waters, "Wilde in the Fifties," in Sex, Knowledge, and Receptions of the Past, ed. Kate Fisher and Rebecca Langlands (Oxford: Oxford University Press, 2015), 267; 271.

${ }^{39}$ Ronnie Peter to James Courage, 3 September 1923, MS-0999/110, HC.

${ }^{40}$ See the correspondence between Webber and various publishers in MS-3333/198, HC.

${ }^{41}$ Anna Blackman, "Locked away: Life in Mount Eden Prison," The Hocken Blog, 19 January, 2011, https://blogs.otago.ac.nz/thehockenblog/2011/01/19/locked-away-life-in-mount-eden-prison/

${ }^{42}$ Typewritten note, MS-333/198, HC.

${ }^{43}$ Bert Pimley, "Rock Orchid," Transcript, MS-3333/197, HC, chapter 3, page 3. Each chapter has its own discrete pagination.

${ }^{44}$ Pimley, "Rock Orchid," ch. 10, p. 6.

${ }^{45}$ Pimley, "Rock Orchid," ch. 5, p. 4.

${ }^{46}$ Pimley, "Rock Orchid," ch. 3, p. 3.

${ }^{47}$ Regina Kunzel, Criminal Intimacy: Prison and the Uneven History of Modern American Sexuality (Chicago: University of Chicago Press, 2008).

${ }^{48}$ Pimley, "Rock Orchid," ch. 3, p. 3.

${ }^{49}$ Pimley, "Rock Orchid," ch. 15, p. 11.

${ }^{50}$ Pimley, "Rock Orchid," ch. 3, p. 5.

${ }^{51}$ Pimley, "Rock Orchid," ch. 3, p. 7.

${ }^{52}$ Pimley, "Rock Orchid," ch. 3, p. 11.

${ }^{53}$ Pimley, "Rock Orchid," ch. 4, p. 11.

${ }^{54}$ Pimley, "Rock Orchid," ch. 9, p. 11.

${ }^{55}$ Brickell, Mates and Lovers, ch. 1. 
${ }^{56}$ See, for instance, Rachel Hope Cleves, Charity and Sylvia: A Same-Sex Marriage in Early America (Oxford: Oxford University Press, 2014); Bev Roberts, "Miss Newcomb's Teapot," The LaTrobe Journal 87 (2011): 74-85; and the analysis in Brickell, Manly Affections, 130-136.

${ }^{57}$ Pimley, "Rock Orchid," ch. 11, p. 11.

${ }^{58}$ Pimley, "Rock Orchid," ch. 3, p. 8. See my analysis of psychiatry and homosexuality since the midnineteenth century in Chris Brickell, "Sexology, the Homo/Hetero Binary, and the Complexities of Male Sexual History," Sexualities 9, no. 4 (2006): 423-27.

${ }^{59}$ Pimley, "Rock Orchid," ch. 16, p. 3.

${ }^{60}$ Pimley, "Rock Orchid," ch. 3, p. 9.

${ }^{61}$ Pimley, "Rock Orchid," ch. 10, p. 6.

${ }^{62}$ Pimley, "Rock Orchid," ch. 6, p. 2.

${ }^{63}$ Kunzel, Criminal Intimacy, ch. 2.

${ }^{64}$ Pimley, "Rock Orchid," ch. 3, p. 8.

${ }^{65}$ Kunzel, Criminal Intimacy, 65.

${ }^{66}$ Pimley, "Rock Orchid," ch. 5, p. 10; ch. 7, p. 7.

${ }^{67}$ Pimley, "Rock Orchid," ch. 14, p. 2.

${ }^{68}$ Pimley, "Rock Orchid," ch. 14, p. 6.

${ }^{69}$ Pimley, "Rock Orchid," ch. 14, p. 7.

${ }^{70}$ Pimley, "Rock Orchid," ch. 15, p. 5.

${ }^{71}$ Pimley, "Rock Orchid," ch. 15, p. 6.

${ }^{72}$ Pimley, "Rock Orchid," ch. 15, p. 6.

${ }^{73}$ Pimley, "Rock Orchid," ch. 15, p. 8.

${ }^{74}$ Susan Stryker, Queer Pulp: Perverted Passions from the Golden Age of the Paperback (San Francisco: Chronicle Books, 2001), 32. On crime and pulp fiction see Michael Bronski, "Gay Male and Lesbian Pulp Fiction and Mass Culture," in The Cambridge History of Gay and Lesbian Literature, ed. E. L. McCallum and Mikko Tuhkanen (Cambridge: Cambridge University Press, 2014), 683.

${ }^{75}$ Bronski, "Gay Male and Lesbian Pulp Fiction,” 677, 685.

${ }^{76}$ Don Goodsell, "The Night Is Young and We're So Beautiful," 1966, unpublished, unpaginated manuscript in the author's possession. Given the lack of pagination, subsequent quotes from this manuscript are not referenced.

${ }^{77}$ Don Goodsell, "Did You Ever See a Dream Limping?” 1966, unpublished, unpaginated manuscript in the author's possession.

${ }^{78}$ Bronski, "Gay Male and Lesbian Pulp Fiction," 689.

${ }^{79}$ John Rechy, City of Night (New York: Grove Press, 1984 [1963]), 27. The eccentric punctuation is in the original.

${ }^{80}$ David Wildey's diary in author's possession; the Tellier and Milton books - and other less wellknown works - are discussed in Anthony Slide, Lost Gay Novels: A Reference Guide to Fifty Works from the First Half of the Twentieth Century (Binghamton: Harrington Park Press, 2003).

${ }^{81}$ Bronski, "Gay Male and Lesbian Pulp Fiction," 683.

${ }^{82}$ Wells, "Introduction," 26.

${ }^{83}$ Pimley, "Rock Orchid," ch. 7, p. 7.

${ }^{84}$ Montgomerie Hyde, The Trials of Oscar Wilde (New York: Dover, 1973), 201.

${ }^{85}$ Brickell, Mates and Lovers, 287. 